\title{
Testing ground: evolving screendance practices and theories and the Leeds International Film Festival Screendance Competition
}

Kyra Norman, University of Falmouth, UK

Keywords: Leeds International Film Festival Screendance Competition, hybridity, nomenclature, epistemology, boundaries

\section{Context}

In 2014, artist Andy Wood and regional art form agency, Yorkshire Dance, began a collaboration with the Leeds International Film Festival (LIFF) to present a Screendance Competition within the Festival's program. LIFF, now in its thirtieth year, is a wellestablished event on the international film circuit. Following film festival convention, the Screendance Competition makes an annual open call for submissions, from which a shortlist of films is then drawn up by the organizers. These selected works are then rated and debated by a panel of expert judges, with all 10 shortlisted films then presented at a public screening during LIFF, after which the winning film is announced and awarded £500. The audience also have the opportunity to vote for their favorite film, which is announced as one of five LIFF Short Film Audience Award winners, drawn from across the festival's screenings.

In its first two years, LIFF SDC has brought together a number of key international artists, curators, and writers engaged in dance and moving image to shortlist, select, present, and discuss the work, including Gitta Wigro, Simon Fildes, Marisa C. Hayes, Claudia Kappenberg, Silvina Szperling, Liz Aggiss, and Leonel Brum.

Following the Screendance Competition at the Leeds International Film Festival in 2015, I was struck by the ways in which this event makes visible, and actively engages with, several issues that seem to define current discourse around screendance. If I review recent writing on screendance, three key questions emerge:

- How might we (screendance artists, curators, audiences and researchers) draw on the separate knowledges and ways of seeing that varied dance and moving 
image practices bring to this hybrid form?

- How might we frame what it is that we are doing in ways that might be useful to audiences?

- How might we establish greater specificity in our discussions of screendance works in ways that might be useful to artists?

Looking into each of these questions offers the potential to change our perceptions of what we are doing and discussing. Here, I begin to trace the ways in which the programming strategies and thinking going on behind the scenes at the LIFF Screendance Competition actively work through and respond to each of these questions.

Chirstinn Whyte has reviewed the 2014 and 2015 LIFF SDC events, and her writing provides a useful summary and thoughtful reflection on the screened films. ${ }^{1}$ Drawing on her work, I have developed a 'review' of the form of the event, rather than the content - a critically engaged response to the context being created, rather than the works screened. My response is intentionally open-ended, indicating the sorts of directions in which our thinking and making might open out from the proposals inherent in this particular event, and across the wider fields of dance and moving image research, practice and presentation.

In their introduction to the 2015 issue of this journal, "Community and Screendance" editors Simon Ellis and Harmony Bench also begin with three questions, focusing on "the networks and support structures that enable each of us to do our work," the "communities [that] we draw from creatively and intellectually," and the "audiences and interlocutors for our work." ${ }^{2}$ It is from this perspective that I reflect on the LIFF Screendance Competition: focusing on ideas of networks, communities, and audiences. I consider the event as a structure supporting artists and researchers to do our work; as a means of engaging creatively and intellectually with different communities, and balancing their needs and desires; and as a project working to engage its audiences in ongoing conversations on the possibilities and potential of screendance. I am interested to reveal the underlying ethos that shapes the event, and to recognize that this ethos is evolving in response to: a) the works submitted; b) ongoing critical discourse; and c) wider questions about life, the universe, and everything which artists ask through making screendance, and audiences ask in response.

This writing is structured around three sets of ideas that emerge from the questions outlined above. First, considering how we bring together dance and screen knowledges, I discuss the implication of positioning screendance in an explicitly 'screen' context, that of a film festival. Second, in relation to how we frame 
screendance, I look at the way that LIFF SDC both works with and against definitions of dance, moving image, and screendance. Third, in terms of how we can find greater specificity in talking about screendance, I consider the judges' statement identifying two distinctive approaches in the works submitted, and trace some connections between this proposition and ongoing discussions around genre and sub-genre in screendance, in particular contributions to the conversation made by Douglas Rosenberg, Noel Carroll, and Anna Heighway.

\section{Screendance in a 'screen' context}

As screendance artist Katrina McPherson writes in Making Video Dance, one attraction for dance artists moving from working in a live to a screen context is the possibility of reaching wider, more diverse audiences than those typically attending contemporary dance performances in contemporary dance spaces. ${ }^{3}$ But, while screendance is widely available online, and occasionally seen on TV, it is still the case that screendance events tend to be presented in dedicated dance spaces - whether venues, festivals, or conferences-and are attended by dance enthusiasts.

The LIFF Screendance Competition's placing of screendance into an event associated with 'screen' rather than 'dance' offers rich potential and a refreshed perspective. The film festival context encourages us to see the films through the lens of screen-related theories and practices, and places screendance in direct comparison with other moving image forms, as opposed to the usual comparisons with live dance. For example, one recurrent issue in relation to how audiences experience screendance work is whether works that lack a visible dancing presence on screen are read as 'dance.' Another area of research into how audiences engage with screendance has focused on kinesthetic empathy: the embodied response of the viewer watching movement on screen. ${ }^{4}$ When considering questions of framing screendance and audience experience at LIFF, I wondered how we might present dance thinking, rather than the doing of dance, on screen. Placing the works within a film context also brought to mind film theorist David Bordwell's discussion of analytical and constructive editing, and the work of Lev Kuleshov: an approach to making work for the screen which recognizes, in Bordwell's pithy summary, that "what happens between shots happens between your ears." ${ }^{5}$ This idea, that the audience for a screen work plays an active role in making connections from shot-to-shot, is a mainstay of Hollywood editing, as well as an established principle motivating avant garde filmmaking. It also seems to be particularly relevant in discussions about audience experiences of screendance. I enjoy the idea that this interpretation of where in your body a film occurs might give us a new perspective on how the audience receives information through watching screendance - distinguishing dance that takes place 'between our ears,' in relation to that which occurs 'before our eyes.' 
In "Toward a Theory of Screendance" Douglas Rosenberg makes a strong case for the inclusion of theories and perspectives from all of the other forms with which screendance intersects-including visual art, film, video, performance-alongside dance, in order to better understand our medium. ${ }^{6}$ Events such as the 2010 What If ... festival, curated by Lucy Cash, Gill Clarke, Becky Edmunds, Claudia Kappenberg, and Chirstinn Whyte and hosted by Siobhan Davies Studios, in London have demonstrated the possibilities of this approach in practice, bringing together a curated program of works from dance, film, live art and performance and contributing a rich mix of perspectives and propositions. ${ }^{7}$ My hope is that LIFF SDC will continue to develop as part of this proactive conversation, situating screendance within film conventions and narratives, and reminding us that, as Rosenberg contends, "screendance is contingent on, but is not, generically, dance."

\section{Framing screendance practice, engaging with different perspectives and possibilities}

The idea that screendance is not simply 'dance,' but a complex hybrid form, is one that has been championed by many artists, producers, and curators over the last fifteen years at least, and in that time there have been many attempts to define the parameters of the field, in order to emphasize this idea. In a paper first presented in 2000, film critic Noël Carroll suggests that debates on what should, or shouldn't, be classified, positioned, or presented as screendance had already become a staple of screendance events, observing that:

Whenever festivals of this sort are held, it is very likely that at one time or another almost everyone present will be tempted to say that some of the work doesn't really belong on the program. Everyone complains about labeling, but sooner or later most people feel compelled to invoke some favorite definition of their own. For human beings, categorizations are unavoidable, even if we like to pretend indifference to them. And most of us can feign indifference only so long; most of us have a breaking point." ${ }^{\prime 9}$

From a UK perspective, commissioning bodies such as ACE, BBC, Channel 4, and organizations that hosted screendance festivals, such as South East Dance and the Place, played an important role in defining the form by determining what works were not eligible for inclusion; for example, documentaries of live performances. Artists such as Becky Edmunds, Simon Aeppli, and Magali Charrier have since worked over and into what Edmunds has described as "the enjoyable gap"10 created by this complicated positioning of 'documentary' and 'screendance.' LIFF's original call for submissions alludes to the creative possibilities of dance documentary, whilst also cautioning against submitting straight-up documentation: "We are not looking for 
documentations of live performance, though we will consider live work creatively reinterpreted specifically for the screen." ${ }^{11}$

LIFF SDC intentionally welcomes hard-to-categorize and innovative work that challenges our perception of how interrelations of 'dance' and 'screen' can play out. To do this, the event both embraces categorization-it is, after all, a 'Screendance Competition'-and also invites the widest possible interpretation of what 'screendance' might be:

This competition seeks out innovative short films that explore the intersection of choreography and cinematography. This could be screenbased work that features dance, or it may have a specific choreographic element in the edit itself; it may use new technologies, animation or webbased work.... How radically the entries interpret choreography on a screen is up to the artists and we invite them to challenge our expectations and surprise us with their imagination! (my emphasis). ${ }^{12}$

Whilst we can assume that all the artists who submitted films felt that their work fell within these purposefully wide boundaries, audience reaction suggests that some present had reached the sort of 'breaking point' that Carroll discusses: the point where what we are seeing no longer accords with our understanding of the form. Erin Brannigan has discussed the long history of dance that "challenges the parameters of human perception"13 and the resultant attraction dance has held for avant garde filmmakers, tracing a history from early cinema, through Surrealism and Dada to the present day. From this perspective it is clear that dance's engagement with experimental moving images practices is long-standing, and that LIFF aims to keep this spirit alive. However, the traditional view of dance and moving image remains that of dancer-as-object represented through moving image, and presenting screendance works outside the usual dance-centerd venues makes clear how far this perception persists. In both 2014 and 2015, heated debate at the screening has been followed by audience members taking to social media to debate and contest the judges' decisions and selections, principally on the grounds of whether the winning work 'is dance.' In response to debates in 2014, a post-show discussion was added to 2015's program in order to give more room to these discussions. In this way the Competition's programming strategies encourage debate in two key ways: through the audience vote mechanism, and also in making room within the event for public debate. Also, by running an open submissions program, LIFF SDC is well-positioned to provide a snapshot of the extent to which artists are currently pushing screendance's parameters.

By intentionally inviting works that challenge our preconceptions of screendance and what it can be, LIFF SDC is part of a wider curatorial/programming movement, visible in dance and moving image as separate forms, to question art form boundaries and to 
provoke debate and discussion. By bringing the work to a wider 'non-dance' audience, new voices and perspectives enter the conversation.

\section{Establishing greater specificity in screendance discourse}

When we talk about 'screendance': what do we mean? And how can we take account of different approaches, priorities, knowledges, and histories? This is a line of enquiry that runs through screendance discourse, and may be traced back through previous issues of the International Journal of Screendance, for example from Douglas Rosenberg's writing on excavating genres within screendance and Carroll's essay, discussed above, in volume 1, through Adam Roberts' "Notes of Filming Dance" in volume 2, and most recently taken up by Anna Heighway in her discussion of "Radical Screendance" in volume 4 . The drive to speak with specificity is not purely academic, since it also allows us to discuss and respond to works in appropriate, direct, and specific ways.

In their closing comments at this year's event, the LIFF Screendance Competition judges (Liz Aggiss, Leonel Brum, and Marisa C. Hayes) acknowledged a particular challenge in this area. Among the diverse works submitted, they had identified two very different approaches to making screendance and they "didn't want their final choice to be read as endorsing one approach over another." 14 The judges saw a clear divide between "works of choreography for human dancers, in partnership with the camera and a site-specific environment," and works that construct choreography from materials and processes, in this case Mariam Eqbal's "Choreography for the Scanner," a film constructed using a still image and a flatbed scanner, creating a simple choreography through repetition, referencing early photographic and cinematic explorations of moving bodies. Might we consider, returning to Bordwell, above, that Eqbal's choreography takes place 'between your ears': that the connection between her activity and the idea of 'dance' takes place in our minds, rather than before our eyes?

In highlighting and finding ways to describe the two distinct approaches, the LIFF Screendance Competition judges feed into ongoing discussions around genres and sub-genres in screendance, a topic on which Douglas Rosenberg has written extensively, urging us to "counter the narrative of screendance as monolithic and without distinction as to genres, medium specificity, or identifiable differences that flow from formal or substantive approaches and concerns..." 15 Rosenberg proposes that "the discourse around screendance would be made stronger by excavating and identifying its generic sources, which would in turn push screendance into a broader and more vital interdisciplinary dialog." ${ }^{16}$ I understand such vitality to be equally important to artists writers and researchers, enabling more appropriate and complex discussions of our work. 
Given the LIFF SDC judges' comments, two pieces of writing seem relevant to consider understand seemingly disparate definitions of screendance: Noël Carroll's paper "Toward a definition of Moving-Picture Dance," and Anna Heighway's essay "Understanding the 'Dance' in Radical Screendance."

Carroll's paper was initially presented at the "Dance for the Camera Symposium" at the University of Wisconsin Madison in 2000, and subsequently published in the Summer 2001 issue of Dance Research Journal, before being reprinted in the first issue of the International Journal of Screendance in 2010. His insistence on accuracy in naming, and his considered refutation of many possible terms is provocative. For example, he argues against then prevalent, medium-specific labels such as cine-dance or dancefilm, and also against the term 'screendance' as an overarching categorization, on the grounds that TV, for example, isn't a screen in the sense of a surface onto which the image is projected, but a means of creating and presenting an image. I find this distinction particularly interesting in that it suggests a shift in the common usage of the word 'screen' in the last 15 years, as we now routinely refer to TV, computers, and smartphones as having screens, independent of any means of projection. The prevalence of terms such as 'screen media' and 'screen time' underline this change. Nevertheless, Carroll opts for 'moving-picture dance' and, again, is very precise in selecting 'moving-picture' over 'moving image,' proposing that where an image can be abstract, a picture offers a recognizable form:

[T] he term moving-picture dance narrows the field to visualizations of recognizable things, specifically to dances, which, it would seem, are necessarily composed literally of humans and human movement, or personifications thereof. So, at least according to me, when I claim that the concept of moving-picture dance describes our field of interest, I am saying that something belongs in our area if and only if it is a moving visual array of recognizably human movement or stillness (or a personification thereof) drawn from an identifiable existing dance vocabulary or a descendent therefrom. Or, more simply but less accurately: a moving-picture dance is a moving picture of dance movement. ${ }^{17}$

Heighway poses the question: "what is the 'dance' in screendance now that the human body has left center stage?" and, a related query, whether audiences are equipped to "identify and appreciate works that have outgrown traditional models." 18 She considers how viewers might access screendance today, both literally and conceptually, and offers an analysis of "works that lie at screendance's outermost edges," which she calls "Radical Screendance." 19

For Heighway, traditional screendance is that which uses the screen to present the dancing body. Radical screendance is that which uses screen practices to explore the nature of dance itself. In traditional screendance, "[t]he 'dance's may have taken the 
shape of formal vocabulary or a looser interpretation of movement as dance, but common to either approach would have been the sight of humans in motion." ${ }^{\prime 20}$ In radical screendance, artists explore a"paradigm in which the 'dance' in screendance need not be 'dance' movement, nor human motion, but anything kinetically driven, full stop." ${ }^{21}$ Heighway's rehearses a history of traditional screendance that begins with Thomas Edison's "Annabelle the Dancer" (1894-95)—which brought together dance and the nascent cinema-and then diverges into two pathways, one mainstream (e.g. Busby Berkeley), one avant garde (e.g. Maya Deren). She then proposes that radical screendance begins from a different premise: looking to the work of Eadweard Muybridge and Étienne-Jules Marey, and then tracing an alternative history of the exploration of movement through screen practices and technologies. For Heighway, laying claim to this alternative history has opened up an expansive range of works to re-consideration, and potential re-classification, considering 'non-dance' works through a choreographic lens.

Both Carroll and Heighway identify a number of subcategories within their main categories. Carroll proposes that 'moving-picture dance' be considered a sort of genus, within which we can then identify species such as "moving-picture dance documentations, moving-picture dance reconstructions, and moving-picture dance constructions," ${ }^{22}$ this last sub-category including all work made specifically for 'moving-picture' presentation. Within her formulation of 'radical screendance,' Heighway identifies four approaches, each arising from different proposals aboutand positionings of-contemporary dance practice. First, she discusses a broad interpretation of 'dance as movement,' which opens up the possibility of working with non-dance movement material to create a screendance, whether that be movement in front of, or by the camera. Second, she considers 'dance as metaphor,' where:

in the absence of 'recognizable' dance content, the 'conceptual links' that must be made in order that we perceive dance nonetheless become consciously embedded into the work by the filmmaker. The intentionality of filmmakers in devising and articulating metaphors, as well as our act of deciphering them, is central to an audience's understanding of dance's significance within these works. ${ }^{23}$

Third, Heighway identifies a 'choreographic' approach to moving image work, where choreography is seen as separable from the act of dancing, and so can be applied as a means of structuring in other areas such as filmmaking. Finally, she delineates a 'somatic' approach, where dance-trained artists utilize physical thinking to approach the process of filmmaking from an embodied perspective. For each of these approaches, Heighway argues that the artists "[do] not ask that we abandon our conventional notions of dance, but rather that we use these as a reference point from which to engage our imaginative understandings of the concept." ${ }^{24}$ 
Heighway's thinking is useful in relation to discussions at LIFF and other screenings and events: the idea of using our sense of what dance 'is' as a point of imaginative departure rather than the endpoint. To return to LIFF, the Screendance Competition demonstrates how an awareness of debates in screendance theory, such as those outlined above, can inform screendance programming strategies in practice. As a form, screendance proceeds and develops through a reflexive interplay of making and thinking, practice and theory. As Claudia Kappenberg and Douglas Roseberg have noted, we are working "at a time when there is an increasing fluidity between theory and practice; when those who 'make' are also those who think beyond the edges of practice, and whose contributions to the field are often sharply defined by [verbal] language." ${ }^{25}$ The LIFF Screendance Competition is one example of the ways in which people engaged in sharing and circulating screendance practice are beginning to use words in particular ways to engage diverse audiences, and draw out responses informed by different reading of the works shown. These perspectives can, in turn, feed back into our understanding of the ways in which screendance is perceived. I believe that such feedback loops, and the informal sharing of ideas, are central to screendance's development. As Bench and Ellis observe: "human beings seek to identify, connect, and converse with others" and accordingly the ways that we communicate our thinking around "why we work together in screendance and the ways in which we work together are key." ${ }^{26}$ However, as they discuss, with fewer festivals and screenings in the UK, screendance artists, here at least, increasingly connect and communicate through virtual means rather than in person. Those contributing to the LIFF Screendance Competition do rely on virtual communications, in order to coordinate international judging panels for example, but, significantly, they are also generating an opportunity for physically getting together and watching and discussing work: and this opens up the conversation to passers-by as well as those already involved in the form.

My key impressions of the LIFF Screendance Competition are of a considered opportunity to bring people, ideas, and practices together: local audiences and international artists, writers, and curators; dance and screen practices and theories; and diverse approaches to creating and conceptualizing relations of dance and moving image. By highlighting some of the ways in which this is happening, and placing a commentary on this evolving event in the context of the International Journal of Screendance, I hope to extend the range and scope of conversations and methods from the event, and others, out into the wider realms of discourse - to make visible to a wider audience the efforts of this event "to incite curiosity and debate about the very nature of the art form." ${ }^{27}$ 


\section{Biography}

Kyra Norman is a dance artist based in Cornwall, UK. She has been following her curiosity as to what, and where, choreography can be for over 15 years: working across dance, theatre and film as a maker, curator, writer and teacher. Kyra is on the Editorial Board of the International Journal of Screendance and an Associate Lecturer at Falmouth University. In 2015, she completed her PhD, exploring the screen as a site for choreographic practice, at the University of Bristol.

\section{Notes}

${ }^{1}$ Chirstinn Whyte, "Leeds International Film Festival."

2 Harmony Bench and Simon Ellis, "Editors' Note," 1.

${ }^{3}$ Katrina McPherson, Making Video Dance, xxvii.

${ }^{4}$ See for example "Watching Dance: Kinesthetic Empathy,"

http://www.watchingdance.org/

${ }^{5}$ David Bordwell, "What happens between shots...."

${ }^{6}$ Douglas Rosenberg, Screendance, 176.

${ }^{7}$ The website for this event is no longer available online, but for an insight into some of the works screened and curatorial strategies, see Chirstinn Whyte's "What If... 2010 Catalogue Essay."

${ }^{8}$ Rosenberg, Screendance, 177.

${ }^{9}$ Noel Carroll, "Toward a Definition of Moving-Picture Dance," 111.

${ }^{10}$ Becky Edmunds, A work of art from a work of art.

${ }^{11}$ LIFF 2015 Call for Submissions.

12 Ibid. My emphasis added.

${ }^{13}$ Erin Brannigan. Dance Film, 125.

${ }^{14}$ LIFF 2015 Jury statements.

${ }^{15}$ Douglas Rosenberg, "Excavating Genres," 63.

${ }^{16}$ lbid.

${ }^{17}$ Noël Carroll, "Toward a Definition of Moving-Picture Dance," 118.

${ }^{18}$ Anna Heighway. "Understanding the 'Dance' in Radical Screendance," 44.

${ }^{19}$ Ibid.

20 lbid.

${ }^{21}$ Idem., 45.

${ }^{22}$ Carroll, 119.

${ }^{23}$ Heighway, 50.

${ }^{24}$ Idem., 51. 
${ }^{25}$ Claudia Kappenberg and Douglas Rosenberg, "Editorial," 7.

${ }^{26}$ Bench and Ellis, 3.

${ }^{27}$ Kappenberg and Rosenberg, “Editorial," 8.

\section{References}

Bench, Harmony and Simon Ellis. "Editors' Note: On Community, Collaboration, and Difference." The International Journal of Screendance. 5 (2015): 1-8.

http://dx.doi.org/10.18061/ijsd.v5i0.4866

Bordwell, David. "What happens between shots happens between your ears." 2008. http://www.davidbordwell.net/blog/2008/02/04/what-happens-between-shotshappens-between-your-ears/

Carroll, Noel. "Toward a Definition of Moving-Picture Dance." The International Journal of Screendance. 1 (2010): 111-125.

Edmunds, Becky. A work of art from a work of art. http://beckyedmunds.com/\#/ondocumentation/4531976852

Heighway, Anna. "Understanding the 'Dance' in Radical Screendance." The International Journal of Screendance. 4 (2014): 44-62.

http://dx.doi.org/10.18061/ijsd.v4i0.4530

Kappenberg, Claudia and Douglas Rosenberg. "Editorial." The International Journal of Screendance. 4 (2014): 5-9. http://dx.doi.org/10.18061/ijsd.v4i0.4560

LIFF 2015 Call for Submissions.

https://www.facebook.com/events/1479975602296764/

LIFF 2015 Jury Statements.

https://www.facebook.com/events/1492156104432642/permalink/151990341499124 4/

McPherson, Katrina. Making Video Dance. Abingdon and New York: Routledge, 2006.

Roberts, Adam. "Notes on Filming Dance." The International Journal of Screendance. 2 (2012): 107-113. 
Rosenberg, Douglas. Screendance: Inscribing the Ephemeral Image. Oxford, New York: Oxford University Press, 2012.

http://dx.doi.org/10.1093/acprof:oso/9780199772612.001.0001 . 2010. "Excavating Genres" in International Journal of Screendance. Vol. 1.

Whyte, Chirstinn. "Leeds International Film Festival: Screendance CompetitionNovember 2014/15." Shiftwork: Unspooled. Posted 24 Nov. 2015.

http://www.unspooled-writing.blogspot.co.uk/2015/11/leeds-international-filmfestival.html

. "What If... 2010 Catalogue Essay." Shiftwork: Unspooled. Posted 20 May 2012. http://www.unspooled-writing.blogspot.co.uk/2012/05/what-if-festival-2010catalogue-essay.html 